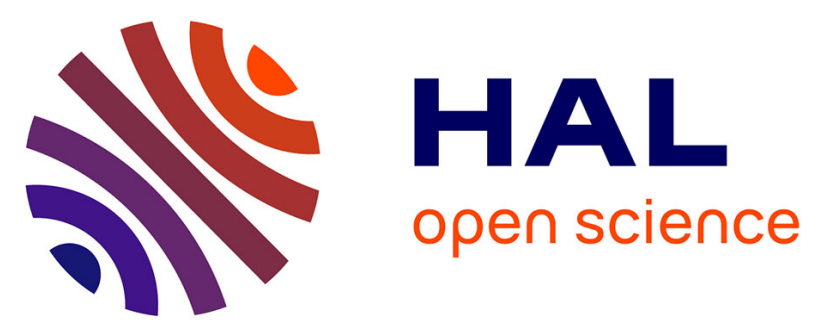

\title{
HPV detection and genotyping of head and neck cancer biopsies by molecular testing with regard to the new oropharyngeal squamous cell carcinoma classification based on HPV status
}

David Veyer, Maxime Wack, Ophélie Grard, Pierre Bonfils, Stéphane Hans, Laurent Bélec, Cécile Badoual, Hélène Péré

\section{To cite this version:}

David Veyer, Maxime Wack, Ophélie Grard, Pierre Bonfils, Stéphane Hans, et al.. HPV detection and genotyping of head and neck cancer biopsies by molecular testing with regard to the new oropharyngeal squamous cell carcinoma classification based on HPV status. Pathology, 2019, 51, pp.421 - 425. 10.1016/j.pathol.2019.02.002 . hal-03484421

\section{HAL Id: hal-03484421 \\ https://hal.science/hal-03484421}

Submitted on 20 Dec 2021

HAL is a multi-disciplinary open access archive for the deposit and dissemination of scientific research documents, whether they are published or not. The documents may come from teaching and research institutions in France or abroad, or from public or private research centers.
L'archive ouverte pluridisciplinaire HAL, est destinée au dépôt et à la diffusion de documents scientifiques de niveau recherche, publiés ou non, émanant des établissements d'enseignement et de recherche français ou étrangers, des laboratoires publics ou privés.

\section{(ㅇ)(1) $\$$}

Distributed under a Creative Commons Attribution - NonCommerciall 4.0 International 


\title{
HPV detection and genotyping of FFPE head and neck cancer biopsies by molecular testing to address new oropharyngeal squamous cell carcinoma classification based on HPV status.
}

Running title: HPV molecular tests comparison on FFPE HNSCC biopsies.

\author{
David Veyer $^{1}$, Maxime Wack ${ }^{4,5}$, Ophélie Grard ${ }^{1}$, Pierre Bonfils ${ }^{3,5}$, Stéphane Hans ${ }^{3 a}$, \\ Laurent Belec $^{1,5}$, Cécile Badoual ${ }^{2,5}$, Hélène Péré ${ }^{1,5, \#}$ \\ ${ }^{1}$ Laboratoire de virologie, Hôpital Européen Georges Pompidou, \\ and Assistance Publique - Hôpitaux de Paris, Paris, France ; \\ ${ }^{2}$ Laboratoire d'anatomo-cytopathologie, Hôpital Européen Georges Pompidou, \\ and Assistance Publique - Hôpitaux de Paris; \\ ${ }^{3}$ Service d'ORL et chirurgie cervico-faciale, Hôpital Européen Georges Pompidou, \\ and Assistance Publique - Hôpitaux de Paris; \\ ${ }^{4}$ Département d'Informatique Médicale, Biostatistiques et Santé Publique, Hôpital Européen \\ Georges Pompidou, and Assistance Publique - Hôpitaux de Paris \\ ${ }^{5}$ Faculté de Médecine Paris Descartes, Université Paris Descartes (Paris V), \\ Sorbonne Paris Cité, Paris
}

Key words: Anyplex II HPV28 Seegene ${ }^{\circledR}$ HPV Genotyping assay; Inno-Lipa ${ }^{\circledR}$ HPV Genotyping Extra II ; HPV16 E6 viral load; HNSCC; FFPE biopsy

Corresponding author :

Dr Hélène Péré

helene.pere@aphp.fr

\footnotetext{
a Stéphane Hans is currently affiliated to the Service d'ORL et de chirurgie cervico-faciale at Hôpital FOCH, UFR Simone Veil, Université Versailles Saint Quentin-en-Yvelines.
} 


\section{Abstract}

35 Recently, both the WHO/IARC (World Health Organisation/International Agency for Research on Cancer) and the American Joint Committee on Cancer (AJCC) have classified the oropharyngeal squamous cell carcinoma (OPSCC) on the basis of HPV status. For this purpose, the WHO/IARC recommended direct molecular HPV testing. In practice, formalinfixed, paraffin-embedded (FFPE) biopsy specimens are frequently the only available samples. We herein compared in parallel two commercially available molecular assays that were firstly designed for cervical HPV detection and genotyping: Inno-Lipa ${ }^{\circledR}$ HPV genotyping extra II assay and Anyplex ${ }^{\mathrm{TM}}$ II HPV 28.

A total of 55 samples were tested. By IL assay, chosen as reference assay, 27 (49.1\%) biopsies were positive for HPV16, 10 (18.2\%) were positive for HPV but negative for HPV16, and $18(32.7 \%)$ were negative for HPV. A valid result with AP28 was obtained for 51 biopsy samples (92.7\%). Among 37 HPV-positive samples by IL, 33 (89.2\%) were positive by AP28. The agreement between both assays was good (Cohen's $\kappa=0.78)$. Among the six discrepancies between assays, always associated with low HPV16 viral load, four biopsies positive for HPV16 by IL could not be detected by AP28. Taken together, these observations demonstrate that both assays could be used in routine for HPV detection and genotyping on FFPE-biopsy samples of head and neck tumour. 


\section{Introduction}

With 600,000 cases per year, head and neck cancer was estimated to be the sixth most common cancer worldwide ${ }^{1}$. Head and neck squamous cell carcinoma (HNSCC) represents $90 \%$ of them. Since 2007, human papillomavirus (HPV) was considered as an independent risk factor for HNSCC by the World Health Organization's International Agency for Research on Cancer (WHO/IARC) ${ }^{2}$. Broad genetic distribution of HPV has been reported in oropharyngeal squamous cell carcinoma (OPSCC), including HPV16 in $85 \%$ of cases, followed by HPV18, 31, 33, 35, 45, 51, 52, 56, 58, 59, 68 and $82^{3,4}$. Finally, OPSCC is currently considered as an epidemic viral-induced carcinoma, since the incidence of HPVpositive carcinoma of the tonsil nearly doubled every 10 years ${ }^{5-8}$.

Recently, the major modification in the eight edition of the American Joint Committee on Cancer (AJCC) Staging Manuel, Head and Neck Section was the introduction of a specific staging algorithm for high-risk (HR) HPV-associated OPSCC ${ }^{9}$. Furthermore, the 2017 edition of the WHO/IARC on Head and Neck tumor classified the OPSCC on the basis of HPV status ${ }^{10-12}$. HPV-positive OPSCC constitutes a tumor entity with better prognosis, a distinct epidemiological profile, with specific genetic features and clinical presentations and outcomes. Immuno-histochemical detection of HPV using p16 staining as surrogate marker of HPV has been until now widely carried out ${ }^{13}$. The 2017-revised WHO/IARC recommendations introduced direct HPV testing based on in-situ hybridization and/or PCR in order to classify the OPSCC according to HPV status ${ }^{12}$. Until now, several commercially available assays have been clinically validated for the detection and genotyping of HPVassociated cervical cancer ${ }^{14,15}$, whereas to our knowledge none have been validated for OPSCC. Furthermore, formalin-fixed, paraffin-embedded (FFPE) biopsy samples are frequently the only available ones for molecular testing after pathological examination. Such 
FFPE samples however necessitate specific processing before PCR analysis because formalin fixation induces fragmentation of nucleic acids ${ }^{16-18}$.

Taken together, the aim of the present study was to evaluate a new multiplex real-time PCR-based assay (Anyplex ${ }^{\mathrm{TM}}$ II HPV 28, Seegene, Seoul, South Korea) (AP28), allowing to detect and genotype a wide range of high-risk HPV genotypes and previously tested for cervical samples ${ }^{19,20}$, in a prospective series of OPSCC FFPE samples, by reference to InnoLipa $^{\circledR}$ HPV genotyping extra II assay (Fujirebio, Gent, Belgium) (IL) chosen as reference assay $^{21-23}$.

\section{Materials and methods}

Collection of biopsy samples and processing. Head and neck biopsy samples received before treatment at the European Georges Pompidou hospital were prospectively included between 2014 and 2017 for routine pathologic examination. Patient had not received any treatment for their cancer at the time of the biopsy. The biopsies were fixed in formalin $10 \%$ overnight and included in paraffin. FFPE-biopsies diagnosed as HNSCC were selected by a pathologist for further cutting in 5- to $20-\mu \mathrm{m}$ sections. Five sections were sent to the ISO 15189-accredited virology laboratory of the hospital for DNA extraction prior to HPV detection and genotyping by IL and, in parallel, by in-house quantitative real-time PCR targeting E6 gene from HPV16 (HPV16 qPCR). Afterwards, same DNA extracts were subjected to multiplex HPV PCR by AP28.

DNA extraction procedures. Sections of FFPE-biopsies were deparaffinised overnight at $+56^{\circ} \mathrm{C}$ with $40 \mu \mathrm{l}$ of proteinase $\mathrm{K}$ (Qiagen, Hilden, Germany) and $360 \mu \mathrm{l}$ of ATL buffer (Qiagen). Afterwards, $200 \mu \mathrm{l}$ of ATL buffer were added and incubated $10 \mathrm{~min}$ at $+70^{\circ} \mathrm{C}$. DNA was further extracted using QiaAmp DNA Mini Kit (Qiagen), and eluted in $50 \mu 1$ of PCR-grade water. For discordant results between IL and AP28, 5 new sections of biopsy 
103

samples were also subjected to DNA extraction procedure optimized for FFPE-biopsies, as

104 previously described by Steinau et al $^{17}$.

105 HPV detection and genotyping in routine. Two molecular HPV assays are used in parallel

106 for routine HPV detection and genotyping on FFPE-biopsies. The IL assay consists of PCR

107 amplification of a small 65 bp-fragment of the L1 gene using SPF10 primers sets and the

108 ubiquitary gene human leukocyte antigen-DPB1 as internal control, followed by hybridization

109 of specific HPV probes in a dedicated automat according to manufacturer's instructions. The

110 IL assay detects 13 HR HPV (HPV -16, -18, -31, -33, -35, -39, -45, -51, -52, -56, -58, -59, -

111 68), 9 low-risk (LR) HPV (HPV -06, -11, -40, -42, -43, -44, -54, -61, -81), 7 genotypes

112 reported as possibly carcinogenic (HPV -26, -53, -66, -67, -70, -73, -82) and 3 genotypes not

113 described as carcinogenic (HPV -62, -83, -89) ${ }^{24}$.

114 HPV16 qPCR was also systematically carried out, as previously described ${ }^{25}$, in order

115 to double check every sample for HPV16 which constitutes the most prevalent HPV genotype

116 in HNSCC ${ }^{26}$, as well as to assess lack of contamination by IL. For quantification, serial

117 dilutions of titrated Caski cells (Amplirun, Orgentec, France) were used to plot external 118 standard curve.

119 Positive controls for HPV16 and HPV18 consisted in DNA extracted from SiHa and 120 HeLa cell lines, respectively; water was used as negative control.

121 HPV detection and genotyping by multiplex PCR. The AP28 assay that distinguishes 28

122 HPV genotypes, by amplifying 100 to 200 bp-fragments of the L1 gene [including 13 HR 123 types (HPV -16, -18, -31, -33, -35, -39, -45, -51, -52, -56, -58, -59, and -68), 8 LR types (HPV $124-6,-11,-40,-42,-43,-44,-54,-61)$ and 7 genotypes reported as possibly carcinogenic (HPV $12526,53,-66,-69,70-73$ and -82)], and human gene $\beta$-globin in two different reactions was 126 used for multiplex HPV molecular testing ${ }^{27}$. Melting curves were obtained at 30, 40, and 50 127 cycles. Results were first automatically analysed using the Seegene Viewer software, version 
2.0 (Seegene) and raw data of results were checked by the virologist. The results were considered as invalid when the negative controls were negative and no HPV was found. An estimation of the viral load was approached by indicating the cycle number at which the positivity was detected: $+(50$ cycles $),++(40$ cycles $)$ and $+++(30$ cycles $)$.

Ethical clearance. All included patients belonged to a cohort declared and approved by the Ethics Committee (Comité de Protection des Personnes Ile de France II, no. 2015-09-04)

Statistical analysis. IL assay was chosen in our laboratory as the reference technique for HPV detection and genotyping, because the assay was reported to show high analytical sensitivity and specificity on FFPE samples ${ }^{28,29}$. Results strictly similar by AP28 and IL assays were defined as identical; results giving at least one identical HPV genotype by AP28 and IL assays were defined as compatible; other results were defined as discordant. Agreement between IL and AP28 assays was assessed by the Cohen's $\kappa$ test: 1 indicating perfect agreement; 1 to 0.81 , very good agreement; 0.80 to 0.61 , good agreement; 0.60 to 0.21; moderate to poor agreement. The Mann-Whitney test was used to compare HPV16 viral loads between samples showing concordant or discordant results. A linear regression model was used to assess the relation between the viral load and the semi-quantitative result of AP28.

\section{Results}

Fifty-five biopsy samples from patients followed for HNSCC were prospectively selected. By the IL assay, 27 (49.1\%) biopsies were HPV16-positive and 10 (18.2\%) were HPV-positive but not HPV16-positive, as depicted in the Table 1. Among the 37 positive samples, 3 (biopsies \#8, \#19 and \#33) were positive for more than one HPV. Finally, 18 (32.7\%) biopsy samples were HPV-negative. 
153 Comparison of HPV detection and genotyping results between IL and AP28 assays.

154 The same DNA extracts from the 55 selected biopsy samples tested by IL were further 155 subjected to AP28 assay. Among 7 discordant samples, one that was initially negative when 156 analyzed with the Seegene Viewer software was finally classified as positive after raw data 157 analysis; the raw data analysis of the remaining discordant samples (corresponding to $10.9 \%$ 158 of samples) gave similar results to the ones obtained by automatic analysis. Final results are

159 shown in the Tables 1 and 2. A valid result with AP28 was obtained for 51 biopsy samples $160(92.7 \%)$ (Table 2). Among the 37 HPV-positive biopsy samples by IL, 33 (89.2\%) were 161 found positive by AP28, including $90.9 \%$ of identical results and $9.1 \%$ of compatible results, 162 the remaining results being either invalid $(n=2)$ or negative $(n=2)$. Finally, the vast majority $163(\mathrm{n}=16 ; 88.9 \%)$ of 18 biopsy samples negative by IL were also negative by AP28; only 2 IL164 negative biopsies were found invalid by AP28. The overall agreement between both assays was good $($ Cohen's $\kappa$ coefficient $=0.78)$. Among the 27 samples that were HPV16-positive with IL, AP28 detected HPV16 in 23 (85.2\%), 2 (7.4\%) were negative and 2 (7.4\%) invalid

167 (Table 1). AP28 did not detect any HPV16 in samples that were negative for HPV16 with IL. 168 Regarding HPV16 detection, the agreement between both assays was good (Cohen's $169 \kappa$ coefficient $=0.75)$.

170 HPV16 viral load. HPV16 qPCR was carried out on the 55 biopsy samples. All HPV16171 positive samples with IL were positive by HPV16 qPCR and all HPV16-negative samples 172 with IL were also negative with HPV16 qPCR (Table 1). The median of HPV16 viral loads 173 was higher in concordant than in discordant samples $[20,800$ copies/ $\mu 1(4.32 \log / \mu 1)$, range, 174 734-595000 versus 503 copies/ $\mu 1$ (2.70 log/ $\mu 1)$, range, 133-512; $\mathrm{P}=0.00077]$. Interestingly, the 175 HPV16 viral loads of IL-positive/AP28-negative results were low (Table 1). As expected, 176 using a linear regression model, a significant relation $(\mathrm{P}=0.000388)$ was observed between the 177 viral load (expressed in $\log _{10}$ ) and the AP28 semi-quantitative results with a linear coefficient 
178 of $0.79 \log$ between each level of AP28 (negative,,+++ and +++ ). The Figure 1 depicts the

179 results of HPV16 viral loads and AP28 semi-quantitative results.

181 Discussion

We herein compared on a large series of FFPE-biopsy samples of HNSCC two

183 commercially available molecular assays targeting L1 gene for routine HPV detection and

184 genotyping. Nearly half of FFPE-biopsy samples from patients followed for HNSCC in our

185 hospital was found positive for HPV DNA using IL as reference assay, emphasizing the need

186 to strictly follow the recent 2017-revised WHO/IARC recommendation of direct HPV testing

187 in case of OPSCC. Both assays showed good agreement for HPV detection as well as for

188 genotyping. However, rare discrepancies between assays could be observed with positive

189 samples for HPV16 by IL which were not detected by AP28. Interestingly, these

190 discrepancies were always associated with low HPV16 viral load. These observations

191 demonstrate that both assays could be used in routine for HPV detection and genotyping on

192 FFPE-biopsy samples of HNSCC, keeping in mind that a few biopsy samples with low

193 HPV16 viral load could be missed. Taken together, our findings clearly emphasize the

194 necessity to validate commercially available molecular assays on patients' biopsy samples,

195 and to confront the results with other molecular technics in case of low HPV viral load.

196 In the present series, the calculated agreement between IL and AP28 results was good,

197 both for HPV16 and other genotypes. However, around ten percent of biopsy samples gave

198 discrepancies between both assays, including biopsies positive for HPV16 by IL which were

199 not detected by AP28. Using HPV16 qPCR, low HPV16 viral load was clearly associated 200 with the misdetection of HPV16 by AP28 assay. Although HPV16 viral load was not 201 normalized on extracted DNA quantity, the experimentations were carried out on the same 202 tissue extract allowing accurate comparison of the results obtained by AP28 and HPV16 
203 qPCR. The capability of IL assay to detect HPV16 in samples harboring low HPV16 viral 204 load is likely due to sufficient amplification efficiency in samples containing fragmented 205 DNA. Indeed, it is well reported that DNA recovering in FFPE specimens may be influenced 206 by several factors, such as formalin quality and concentration, length of fixation, paraffin 207 quality and temperature ${ }^{30}$. As a consequence, DNA in FFPE biopsy is either completely or 208 partially degraded into DNA fragments of $200 \mathrm{bp}$ or less ${ }^{16}$. The IL assay relies on the 209 amplification of shorter fragments than AP28 assay, a feature which could partly explain the 210 discrepancies observed between both assays in our series. Furthermore, discordant results 211 could also be associated with extract quantity used for experiment. Thus, the IL assay requires 212 more quantity of tissue extract $(10 \mu \mathrm{l})$ than AP28 $(5 \mu 1)$, according to manufacturers' 213 instructions. The possibility may be also envisioned that mutations affecting the priming sites 214 of AP28 primers could have led to misdetection. This hypothesis should be however ruled out 215 because the correlation between the efficiency of detection by AP28 and HPV16 viral load 216 was marked. Finally, we checked that observed discrepancies were not due to extraction 217 procedures.

218 In our series, one negative sample by AP28 which was positive by IL was finally 219 diagnosed as positive for HPV16 after analysis of the raw data. This finding indicates that raw data of every AP28 negative samples need to be analyzed in order to detect some of the falsenegative results. Indeed, the automatic analysis and cut-off used by AP28 test may miss out some HPV-positive samples since the assay was primarily designed to detect HPV on either cervical swab or liquid based cytology specimen and not on FFPE samples from 224 oropharyngeal origin. In practice, the automatic Seegene software interpretation should be 225 used with caution for negative or invalid FFPE biopsies. 
only one study compared the performance of the AP28 assay and the CLART system from Genomica (Madrid, Spain) on only 3 FFPE HNSCC samples ${ }^{27}$. In our series, the IL assay appeared as sensitive as in-house HPV16 qPCR, in keeping with previous reports showing that IL is highly reliable on FFPE archival samples. Nevertheless, the AP28 technic could be preferred depending on the recruitment of the laboratory, particularly if the number of samples is important. Indeed, AP28 relies on real-time PCR, which allows easier and faster procedure as compared with IL technic which appears more cumbersome and requires specific material for hybridization on membrane following PCR amplification. In addition, the risk of cross contamination between samples is less important with AP28 than with IL. However, it should be kept in mind that misdetection of HPV16-positive biopsies could occur with AP28 assay. Since HPV16 is known to be the most prevalent HPV genotype in OPSCC, diagnosed in $85 \%$ of cases ${ }^{26}$, one could strongly recommend confirming the negative results by AP28 with HPV16 genotype-specific molecular assay validated on FFPE samples. In our laboratory, we have chosen to screen first for HPV16 by in-house HPV16 qPCR, and then to test further the negative samples with IL or AP28 to potentially detect less common genotypes in OPSCC, or confirm the negativity for HPV.

In conclusion, our observations demonstrate that both commercially available IL and AP28 assays could be used in clinical laboratories with similar performances in routine on OPSCC FFPE samples, in order to address the recent recommendations for direct HPV testing in OPSCC ${ }^{12}$. Nevertheless, low HPV viral load in FFPE biopsy samples could be a limiting factor, rendering in medical practice the diagnosis of HPV in OPSCC sometimes difficult. Finally, HPV diagnosis and genotyping in OPSCC may necessitate several complementary technics, to overcome the limitation of some commercially available assays. 
253 Authors' contributions. DV, OG, CB and HP have conceived and designed the research;

254 OG, has performed the experiments; MW performed statistical analyses; DV, PB, SH, CB and 255 HP analyzed the results ; DV, LB and HP drafted the manuscript.

256 Funding. No grant was received for the study.

257

258 


\section{References}

260 1. Dayyani F, Etzel CJ, Liu M, Ho C-H, Lippman SM, Tsao AS. Meta-analysis of the impact of human papillomavirus (HPV) on cancer risk and overall survival in head and neck squamous cell carcinomas (HNSCC). Head Neck Oncol [Internet]. 2010 Jun 29 [cited 2018 Mar 26];2(1):15. Available from: http://www.ncbi.nlm.nih.gov/pubmed/20587061

2. IARC Working Group on the Evaluation of Carcinogenic Risks to Humans. Human papillomaviruses. IARC Monogr Eval Carcinog risks to humans [Internet]. 2007 [cited 2018 Jul 6];90:1-636. Available from: http://www.ncbi.nlm.nih.gov/pubmed/18354839

3. Kreimer AR, Clifford GM, Boyle P, Franceschi S. Human Papillomavirus Types in Head and Neck Squamous Cell Carcinomas Worldwide: A Systematic Review. Cancer Epidemiol Biomarkers Prev [Internet]. 2005 Feb 1 [cited 2018 Mar 26];14(2):467-75. Available from: http://www.ncbi.nlm.nih.gov/pubmed/15734974

4. Si-Mohamed A, Badoual C, Hans S, Péré H, Tartour E, Brasnu D. An unusual human papillomavirus type 82 detection in laryngeal squamous cell carcinoma: case report and review of literature. J Clin Virol [Internet]. 2012 Jun [cited 2018 Mar 26];54(2):190-3. Available from: http://linkinghub.elsevier.com/retrieve/pii/S1386653212000923

5. Ryerson AB, Peters ES, Coughlin SS, Chen VW, Gillison ML, Reichman ME, et al. Burden of potentially human papillomavirus-associated cancers of the oropharynx and oral cavity in the US, 1998-2003. Cancer [Internet]. 2008 Nov 15 [cited 2018 Mar 26];113(10 Suppl):2901-9. Available from: http://doi.wiley.com/10.1002/cncr.23745

280 6. Hocking JS, Stein A, Conway EL, Regan D, Grulich A, Law M, et al. Head and neck cancer in Australia between 1982 and 2005 show increasing incidence of potentially HPV-associated oropharyngeal cancers. Br J Cancer [Internet]. 2011 Mar 1 [cited 2018 
284 7. Näsman A, Attner P, Hammarstedt L, Du J, Eriksson M, Giraud G, et al. Incidence of 285 human papillomavirus (HPV) positive tonsillar carcinoma in Stockholm, Sweden: An epidemic of viral-induced carcinoma? Int J Cancer [Internet]. 2009 Jul 15 [cited 2018 Jul 6];125(2):362-6. Available from: http://www.ncbi.nlm.nih.gov/pubmed/19330833

8. Chaturvedi AK. Epidemiology and Clinical Aspects of HPV in Head and Neck Cancers. Head Neck Pathol [Internet]. 2012 Jul 3 [cited 2018 Mar 26];6(S1):16-24. Available from: http://www.ncbi.nlm.nih.gov/pubmed/22782220

9. Lydiatt WM, Patel SG, O’Sullivan B, Brandwein MS, Ridge JA, Migliacci JC, et al. Head and Neck cancers-major changes in the American Joint Committee on cancer eighth edition cancer staging manual. CA Cancer J Clin [Internet]. 2017 Mar [cited 2018 Nov 9];67(2):122-37. Available from: http://doi.wiley.com/10.3322/caac.21389

10. Westra WH, Lewis JS. Update from the 4th Edition of the World Health Organization Classification of Head and Neck Tumours: Oropharynx. Head Neck Pathol [Internet]. 2017 Mar 28 [cited 2018 Mar 26];11(1):41-7. Available from: http://www.ncbi.nlm.nih.gov/pubmed/28247229

11. El-Naggar AK, Chan JKC, Takata T, Grandis JR, Slootweg PJ. The fourth edition of the head and neck World Health Organization blue book: editors' perspectives. Hum Pathol [Internet]. 2017 Aug [cited 2018 Mar 26];66:10-2. Available from: http://linkinghub.elsevier.com/retrieve/pii/S0046817717301715

12. El-Naggar AK, Chan JKC, Rubin Grandis J, Takata T, Slootweg PJ, International Agency for Research on Cancer. WHO classification of head and neck tumours [Internet]. [cited 2018 Jul 6]. 347 p. Available from: http://publications.iarc.fr/BookAnd-Report-Series/Who-Iarc-Classification-Of-Tumours/Who-Classification-Of-HeadAnd-Neck-Tumours-2017 
of the efficacy of the 4 tests (p16 immunochemistry, polymerase chain reaction, DNA, and RNA in situ hybridization) to evaluate a human papillomavirus infection in head and neck cancers: a cohort of 348 French squamous cell carcinomas. Hum Pathol [Internet]. 2018 Aug [cited 2018 Sep 25];78:63-71. Available from: http://www.ncbi.nlm.nih.gov/pubmed/29684499

14. Arbyn M, Snijders PJF, Meijer CJLM, Berkhof J, Cuschieri K, Kocjan BJ, et al. Which high-risk HPV assays fulfil criteria for use in primary cervical cancer screening? 2015 [cited 2018 Sep 25]; Available from: http://dx.doi.org/10.1016/j.cmi.2015.04.015

15. Hesselink AT, Sahli R, Berkhof J, Snijders PJF, van der Salm ML, Agard D, et al. Clinical validation of Anyplex ${ }^{\mathrm{TM}}$ II HPV HR Detection according to the guidelines for HPV test requirements for cervical cancer screening. J Clin Virol [Internet]. 2016 Mar [cited 2018 Sep 25];76:36-9. Available from: http://www.ncbi.nlm.nih.gov/pubmed/26809131

16. Gilbert MTP, Haselkorn T, Bunce M, Sanchez JJ, Lucas SB, Jewell LD, et al. The isolation of nucleic acids from fixed, paraffin-embedded tissues-which methods are useful when? Volff J-N, editor. PLoS One [Internet]. 2007 Jun 20 [cited 2018 Mar 26];2(6):e537. Available from: http://dx.plos.org/10.1371/journal.pone.0000537

17. Steinau M, Patel SS, Unger ER. Efficient DNA extraction for HPV genotyping in formalin-fixed, paraffin-embedded tissues. J Mol Diagn [Internet]. 2011 Jul [cited 2018 Mar 26];13(4):377-81. Available from: http://linkinghub.elsevier.com/retrieve/pii/S1525157811001140

330 18. Kocjan BJ, Hošnjak L, Poljak M. Detection of alpha human papillomaviruses in archival formalin-fixed, paraffin-embedded (FFPE) tissue specimens. J Clin Virol [Internet]. 2016 Mar [cited 2018 Mar 26];76 Suppl 1:S88-97. Available from: http://linkinghub.elsevier.com/retrieve/pii/S1386653215006927 
334 19. Kwon M-J, Roh KH, Park H, Woo H-Y. Comparison of the Anyplex II HPV28 assay with the Hybrid Capture 2 assay for the detection of HPV infection. J Clin Virol [Internet]. 2014 Apr [cited 2018 Mar 26];59(4):246-9. Available from: http://linkinghub.elsevier.com/retrieve/pii/S1386653214000353

20. Estrade C, Sahli R, McAdam AJ. Comparison of Seegene Anyplex II HPV28 with the PGMY-CHUV assay for human papillomavirus genotyping. J Clin Microbiol [Internet]. 2014 Feb 1 [cited 2018 Mar 26];52(2):607-12. Available from: http://jcm.asm.org/cgi/doi/10.1128/JCM.02749-13

21. Alberizzi P, Spinillo A, Gardella B, Cesari S, Silini EM. Evaluation of the HPV typing INNO-LiPA EXTRA assay on formalin-fixed paraffin-embedded cervical biopsy samples. J Clin Virol [Internet]. 2014 Dec [cited 2017 Aug 9];61(4):535-9. Available from: http://linkinghub.elsevier.com/retrieve/pii/S138665321400403X

22. Castro FA, Koshiol J, Quint W, Wheeler CM, Gillison ML, Vaughan LM, et al. Detection of HPV DNA in paraffin-embedded cervical samples: a comparison of four genotyping methods. BMC Infect Dis [Internet]. 2015 Dec 25 [cited 2017 Aug 9];15(1):544. Available from: http://www.ncbi.nlm.nih.gov/pubmed/26607224

23. St Guily JL, Jacquard A-C, Prétet J-L, Haesebaert J, Beby-Defaux A, Clavel C, et al. Human papillomavirus genotype distribution in oropharynx and oral cavity cancer in France--The EDiTH VI study. J Clin Virol [Internet]. 2011 Jun [cited 2018 Mar 26];51(2):100-4. Available from: http://linkinghub.elsevier.com/retrieve/pii/S1386653211001077

24. IARC Working Group on the Evaluation of Carcinogenic Risks to Humans., International Agency for Research on Cancer. A review of human carcinogens. Biological agents. [Internet]. International Agency for Research on Cancer; 2012 [cited 2018 Oct 17]. 475 p. Available from: http://publications.iarc.fr/Book-And-Report- 
Series/Iarc-Monographs-On-The-Evaluation-Of-Carcinogenic-Risks-ToHumans/Biological-Agents-2012

361

362

363

25. Prétet J-L, Dalstein V, Monnier-Benoit S, Delpeut S, Mougin C. High risk HPV load estimated by Hybrid Capture II ${ }^{\circ}$ correlates with HPV16 load measured by real-time PCR in cervical smears of HPV16-infected women. J Clin Virol [Internet]. 2004 Oct [cited 2018 Jul 6];31(2):140-7. Available from: http://www.ncbi.nlm.nih.gov/pubmed/15364271

26. Gillison ML, Chaturvedi AK, Anderson WF, Fakhry C. Epidemiology of Human Papillomavirus-Positive Head and Neck Squamous Cell Carcinoma. J Clin Oncol [Internet]. 2015 Oct 10 [cited 2018 Mar 26];33(29):3235-42. Available from: http://www.ncbi.nlm.nih.gov/pubmed/26351338

27. Lillsunde Larsson G, Carlsson J, Karlsson MG, Helenius G. Evaluation of HPV Genotyping Assays for Archival Clinical Samples. J Mol Diagn [Internet]. 2015 May [cited 2018 Mar 26];17(3):293-301. Available from: http://linkinghub.elsevier.com/retrieve/pii/S1525157815000410

28. Gravitt PE, van Doorn LJ, Quint W, Schiffman M, Hildesheim A, Glass AG, et al. Human papillomavirus (HPV) genotyping using paired exfoliated cervicovaginal cells and paraffin-embedded tissues to highlight difficulties in attributing HPV types to specific lesions. J Clin Microbiol [Internet]. 2007 Oct 1 [cited 2017 Aug 9];45(10):3245-50. Available from: http://jcm.asm.org/cgi/doi/10.1128/JCM.00216-07

29. Tan SE, Garland SM, Rumbold AR, Tabrizi SN. Comparison of the INNO-LiPA and PapType assays for detection of human papillomavirus in archival vulva dysplasia and/or neoplasia tissue biopsy specimens. J Clin Microbiol [Internet]. 2011 Nov [cited 2017 Aug 9];49(11):3980-2. Available from: http://jcm.asm.org/lookup/doi/10.1128/JCM.00516-11 
384 30. Klopfleisch R, Weiss ATA, Gruber AD. Excavation of a buried treasure--DNA, mRNA, miRNA and protein analysis in formalin fixed, paraffin embedded tissues. Histol Histopathol [Internet]. 2011 [cited 2018 Mar 26];26(6):797-810. Available from: http://www.ncbi.nlm.nih.gov/pubmed/21472693

388 
390 Table 1. HPV detection and genotyping by IL, AP28 and E6 HPV-16 detection and quantification by in-

391 house PCR of 37 IL-positive FFPE-biopsies diagnosed as HNSCC. HPV 16-positive samples are presented

392 by increasing viral load.

\begin{tabular}{|c|c|c|c|c|}
\hline \multirow{2}{*}{ ID } & \multicolumn{2}{|c|}{ HPV genotyping results } & \multicolumn{2}{|c|}{ In-house E6 HPV16 PCR } \\
\hline & IL & $\begin{array}{c}\text { AP28 } \\
\left(\text { semi-quantitative results }{ }^{\mathrm{a}}\right)\end{array}$ & $\begin{array}{l}\text { Qualitative } \\
\text { results }\end{array}$ & $\begin{array}{c}\text { Viral load } \\
{[\text { copies } / \mu 1(\log )]}\end{array}$ \\
\hline$\# \mathbf{3}$ & HPV16 & Invalid $^{\mathrm{b}}$ & Positive & ND \\
\hline$\# \mathbf{5}$ & HPV16 & Invalid $^{\mathrm{b}}$ & Positive & $133(2.12)$ \\
\hline$\# 7$ & HPV16 & Negative $^{b}$ & Positive & $503(2.70)$ \\
\hline$\# 4$ & HPV16 & Negative $^{b}$ & Positive & $512(2.72)$ \\
\hline$\# 30$ & HPV16 & HPV16 (+) & Positive & $734(2.87)$ \\
\hline \#50 & HPV16 & HPV16 (++) & Positive & $3,910(3.59)$ \\
\hline$\# 33$ & HPV16; HPV82 & HPV16 (+) & Positive & $4,000(3.60)$ \\
\hline$\# 9$ & HPV16 & HPV16 (++) & Positive & $4,860(3.69)$ \\
\hline$\# 14$ & HPV16 & HPV16 (++) & Positive & $5,010(3.70)$ \\
\hline \#46 & HPV16 & HPV16 (++) & Positive & $5,070(3.70)$ \\
\hline$\# 10$ & HPV16 & HPV16 (++) & Positive & $5,360(3.73)$ \\
\hline$\# 45$ & HPV16 & HPV16 (++) & Positive & $5,650(3.75)$ \\
\hline$\# 35$ & HPV16 & HPV16 (++) & Positive & $7,730(3.89)$ \\
\hline$\# 13$ & HPV16 & HPV16 (+) & Positive & $9,230(3.97)$ \\
\hline$\# 49$ & HPV16 & HPV16 (++) & Positive & $20,200(4.31)$ \\
\hline$\# 44$ & HPV16 & HPV16 (++) & Positive & $20,800(4.32)$ \\
\hline$\# 12$ & HPV16 & HPV16 (+) & Positive & $35,200(4.55)$ \\
\hline$\# 2$ & HPV16 & HPV16 (+) & Positive & $40,200(4.60)$ \\
\hline$\# 48$ & HPV16 & HPV16 (++) & Positive & $78,300(4.89)$ \\
\hline$\# 11$ & HPV16 & HPV16 (++) & Positive & $78,400(4.89)$ \\
\hline$\# 32$ & HPV16 & HPV16 (++) & Positive & $80,200(4.90)$ \\
\hline$\# 16$ & HPV16 & HPV16 (++) & Positive & $82,400(4.92)$ \\
\hline$\# 6$ & HPV16 & HPV16 (++) & Positive & $112,000(5.05)$ \\
\hline$\# 27$ & HPV16 & HPV16 (++) & Positive & $128,000(5.11)$ \\
\hline \#39 & HPV16 & HPV16 (++) & Positive & $183,000(5.26)$ \\
\hline$\# 1$ & HPV16 & HPV16 (++) & Positive & $323,000(5.51)$ \\
\hline$\# 42$ & HPV16 & HPV16 (+++) & Positive & $595,000(5.77)$ \\
\hline$\# 34$ & HPV6 & HPV6 (++) & Negative & NA \\
\hline$\# 43$ & HPV6 & HPV6 (++) & Negative & NA \\
\hline$\# 18$ & HPV11 & HPV11 (++) & Negative & NA \\
\hline$\# 31$ & HPV11 & HPV11 (++) & Negative & NA \\
\hline$\# 40$ & HPV11 & HPV11 (++) & Negative & $\mathrm{NA}$ \\
\hline$\# 19$ & HPV18; HPV39p & HPV18 (++) & Negative & NA \\
\hline$\# 47$ & HPV18 & HPV18 (+++) & Negative & NA \\
\hline$\# 8$ & HPV33; HPV52p & HPV33 (+++) & Negative & $\mathrm{NA}$ \\
\hline$\# 38$ & HPV59 & HPV59 (++) & Negative & NA \\
\hline$\# 22$ & HPV82 & HPV82 (+++) & Negative & NA \\
\hline
\end{tabular}

393 a Semi-quantitative results are given in brackets (detection of signal at 30 cycles: +++ ; 40 cycles: ++ ; 50 cycles: +);

$394 \quad{ }^{b}$ Results checked manually without the automated analysis software (Seegene Viewer version 2.0, Seegene). 
395 IL: Inno-Lipa ${ }^{\circledR}$ HPV genotyping extra II assay (Fujirebio, Gent, Belgium); AP28: Anyplex ${ }^{\mathrm{TM}}$ II HPV 28, Seegene (Seoul, South 396 Korea); NA: Not attributable; ND: Not done; p: probable

397

398 
400 Table 2. Qualitative detection of HPV by IL and AP28

401 asays in 55 FFPE-biopsies diagnosed as HNSCC.

402

403

404

405

406

407

408

409

410

411

412

413

414

415

416

417

\begin{tabular}{ll}
\hline IL/AP28 results & N (\%) \\
\hline
\end{tabular}

\section{Concordant results}

- Positive/Positive

33 (60.0)

- Identical

$30(90.9)^{\mathrm{a}, \mathrm{b}}$

- Compatible

$3(9.1)^{\mathrm{c}}$

. Negative/Negative

$16(29.1)$

Discordant results

. Positive/Negative

2 (3.6)

. Positive/Invalid

$2(3.6)$

. Negative/Invalid

2 (3.6)

418

419

$\overline{\text { a In brackets: percentage of IL/AP28 concordant out of total Positive/Positive; }}$

$420 \quad$ b Among discordant samples, only one initially negative by Seegene Viewer

421 software (Seegene) showed raw data compatible with positivity, and was

422 classified as positive sample;

$423{ }^{\mathrm{c}}$ In brackets: percentage of IL/AP28 compatible out of total Positive/Positive.

424 IL: Inno-Lipa ${ }^{\circledR}$ HPV genotyping extra II assay (Fujirebio, Gent, Belgium);

425 AP28: Anyplex ${ }^{\mathrm{TM}}$ II HPV 28, Seegene (Seoul, South Korea)

426 
428 Legend for the figure

429 Figure 1. Comparison of HPV16 viral loads (in-house qPCR) and HPV16 AP28 semi430 quantitative results. HPV16 semi-quantitative results are presented as negative,,+++ and +++ 431 according to the cycle at which the signal is detected (no detection, detection at 50, 40 and 30 432 cycles respectively). The Spearman's rank correlation test is shown on the figure ( $\mathrm{R}=0.54$, $433 \mathrm{p}=0.0058)$.

434 
$6-$ Spearman's rank correlation test: $R=0.54 \quad p=0.0058^{\star \star}$
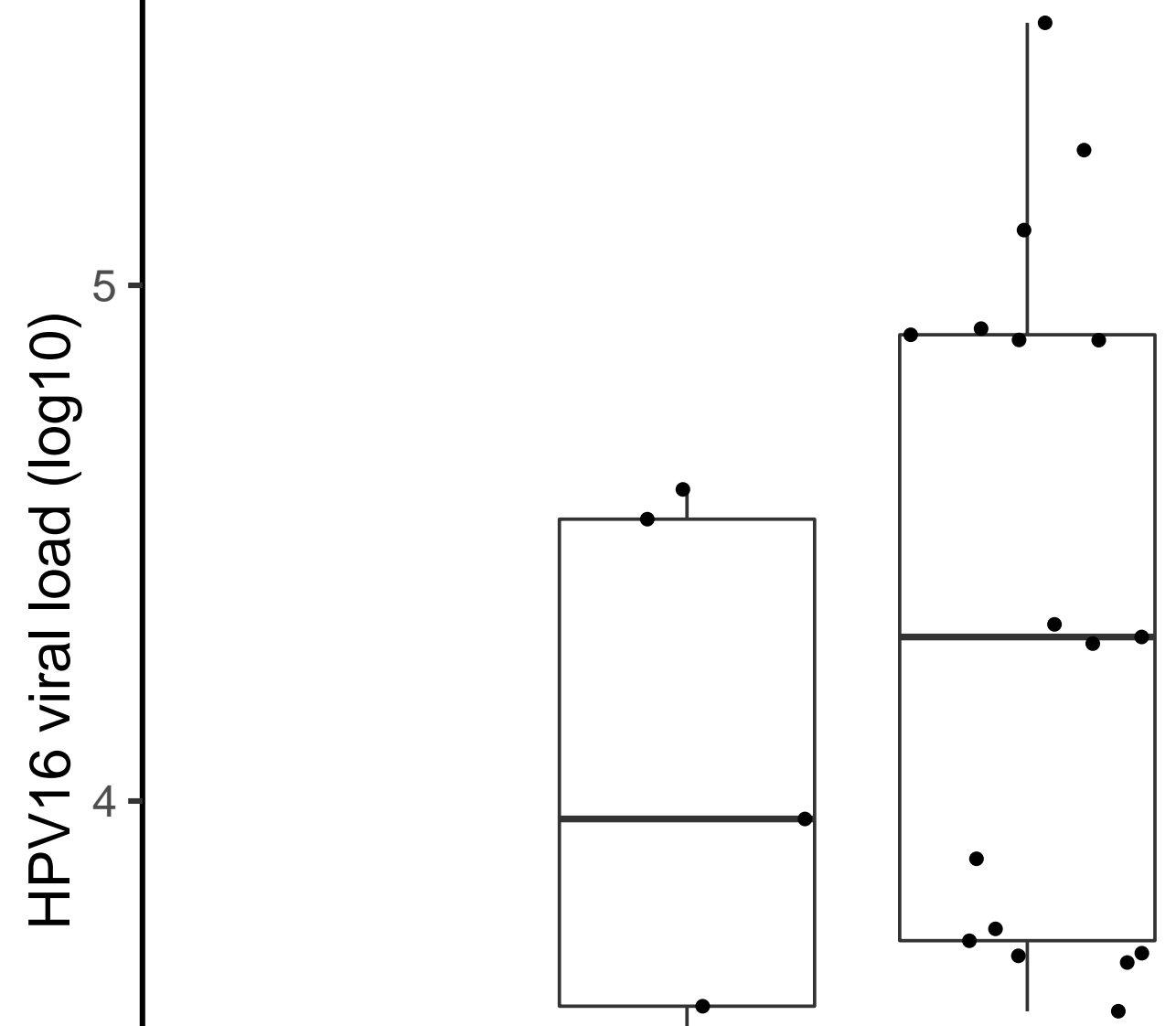

3

Negative

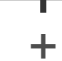

$++$

$+++$

AP28 semi-quantitative result 